\title{
Hubungan Peran Orang Tua dengan Motivasi Akademik Siswa
}

\author{
Diah Puspitasari* \\ Sekolah Menengah Pertama Negeri 23 Malang, Jl. Raya Tlogowaru No.2 Malang, Jawa Timur, \\ Indonesia \\ *Penulis korespondensi, Surel: diahpuspitasari77@guru.smp.belajar.id
}

Paper received: 28-9-2021; revised: 12-10-2021; accepted: 19-10-2021

\begin{abstract}
The purpose of this study was to determine the relationship between academic motivation and the role of parents during the distance learning/pandemic period in grade 7 at SMPN 23 Malang City. This type of research is a correlation. The population of this study was all students of SMP Negeri 23 Malang with a sampling technique using purposive random sampling with a sample of 144 students. The study results illustrate that there is a significant relationship between the role of parents and academic motivation at SMPN 23 Malang.
\end{abstract}

Keywords: the role of parents; motivation to learn; correlation

\begin{abstract}
Abstrak
Penelitian ini bertujuan untuk mengetahui hubungan motivasi akademik dengan peran orangtua pada masa pembelajaran jarak jauh/masa pandemi di kelas 7 di SMPN 23 Kota Malang. Jenis penelitian yang digunakan adalah korelasi. Populasi penelitian ini adalah siswa kelas VII SMP Negeri 23 Malang dan teknik pengambilan sampel menggunakan purposive random sampling. Jumlah sampel penelitian sebanyak 144 siswa. Hasil penelitian memberikan gambaran bahwa terdapat hubungan yang signifikan antara peran orang tua dengan motivasi akademik di SMPN 23 Malang.
\end{abstract}

Kata kunci: peran orang tua; motivasi belajar; korelasi

\section{Pendahuluan}

Covid 19 adalah salah virus yang sejak tahun 2020 kita semua ketahui menyerang dunia termasuk Indonesia, berasal dari Wuhan Cina hingga kini, dan berdampak besar pada semua sektor, baik ekonomi, sosial, politik, budaya, dan pendidikan. Hal tersebut membuat munculnya kebijakan PSBB (Pembatasan Sosial Berskala Besar) di beberapa wilayah dan aktivitas menjadi terganggu (19 Maret 2020, dari Kompas .com). Sejak diumumkan tanggal 19 Maret 2020 maka muncul peraturan dan pandemi membuat perubahan pada proses pembelajaran, dan menyebabkan pembelajaran dilakukan secara online/dalam jaringan. Model pembelajaran ini didasarkan Surat Edaran dari Kementrian Pendidikan dan Kebudayaan atau Kemendikbud No 15 Tahun 2020 mengenai Pedoman Penyelenggaraan Belajar dari rumah dalam Masa Darurat penyebaran covid-19. Pembelajaran secara online ternyata menyulitkan bagi sebagian orang, banyak kendala yang dialami baik guru, murid, orangtua dan masyarakat. Bagi murid pembelajaran online merubah cara belajar anak dan berinteraksi sosial. Anak yang terbiasa belajar bersama teman dan bimbingan guru mau tidak mau dituntut untuk dapat belajar secara mandiri di rumah.

Hal ini menjadi tantangan bagi guru, orang tua, dan murid untuk berkolaborasi menciptakan kondisi belajar yang efektif dan bermakna. Banyak hal dan upaya yang dilakukan guru untuk dapat memfasilitasi pembelajaran daring dengan banyak mengikuti pelatihan pengembangan diri, akan tetapi hal tersebut tidak cukup menjawab tantangan yang membuat siswa termotivasi dalam belajar dan menyelesaikan tugas-tugasnya. Yang terjadi adalah 
banyak keluhan terkait penurunan kedisiplinan anak dalam mengumpulkan tugas, kehadiran, dan keaktifan dalam belajar. Hal tersebut juga diungkap oleh Adnetya, dkk. (2020) kondisi belajar daring menyebabkan guru kesulitan dan kurang dapat mengontrol iklim belajar, bahkan diperparah dengan penurunan motivasi belajar siswa, sehingga hasil belajar siswa menjadi kurang optimal.

Fenomena tersebut membuat penulis berpikir untuk berupaya lebih keras dan berinisiatif mengajak orang tua untuk peduli terhadap pembelajaran daring di rumah. Alasan dari pelibatan orang tua adalah orangtua memiliki waktu lebih banyak dalam mendampingi dan mengontrol kegiatan anak belajar di rumah selama masa pandemi. Dan peran baru orang tua adalah sebagai partner guru dalam mengajar anak di rumah. Tantangan bagi orang tua adalah bagaimana mereka dapat menjalankan peran ganda yakni sebagai pencari nafkah, mereka juga berperan sebagai guru di rumah. Menurut Ari (2020) peran orang tua sangat penting untuk membantu siswa mencapai prestasi belajar yang optimal melalui dorongan dan rangsangan untuk perkembangan prestasi anak dan melewati hambatan selama proses belajar. Hal ini dapat dikatakan bahwa orangtua sebagai penunjang dari kesuksesan belajar anak.

Namun kondisi motivasi siswa pada masa daring tidak demikian, Dedi (2020) menyatakan bahwa selama pembelajaran daring, siswa belum dapat mencapai hasil belajar yang optimal dan dibutuhkan upaya untuk meningkatkan motivasi belajar. Tidak maksimal disini dalam arti motivasi belajar anak mengalami penurunan hampir disemua mata pelajaran, keluhan dari para guru tentang tugas dari beberapa anak yang sangat jarang untuk dikumpulkan, dan bentuk bentuk lain. An Nisa dkk. (2021) menyatakan bahwa penurunan motivasi belajar disebabkan oleh faktor internal, seperti kejenuhan dan minat belajar, sedangkan faktor eksternal, seperti lingkungan, sarana prasarana, dan kondisi keluarga.

\section{Metode}

Penelitian ini merupakan korelasi untuk mengetahui hubungan antara motivasi akademik dengan peran orang tua. Metode korelasi merupakan salah satu jenis penelitian kuantitatif dan tidak menyatakan sebab-akibat, namun menunjukkan kuat lemahnya hubungan (Coskun \& Topkaya, 2020, Mills \& Mills, 2020). Sampel penelitian ini adalah siswa kelas 7 SMP Negeri 23 Malang sebanyak 144 siswa. Teknik pengambilan sampel menggunakan purposive random sampling sebab siswa kelas VII SMP merupakan masa transisi dari sekolah dasar menuju sekolah menengah. Teknik pengumpulan data menggunakan skala motivasi akademik dan skala peran orang tua yang dikembangkan berdasarkan teori dan hasil penelitian sebelumnya. Hasil reliabilitas terhadap skala motivasi akademik yaitu 0,957 dengan pernyataan yang valid sebanyak 30 item. Sedangkan, perhitungan reliabilitas peran orang tua yaitu 0,972 dengan pernyataan yang valid sebanyak 30 item. Teknik analisis data menggunakan korelasi bivariat, Krepelkova dkk. (2020) menyatakan bahwa korelasi bivariat untuk mengetahui hubungan antara dua variabel. Hubungan antar-variabel yang dimaksudkan yaitu motivasi akademik dan peran orang tua.

\section{Hasil dan Pembahasan}

\subsection{Hasil}

Tujuan penelitian ini untuk mengetahui hubungan peran orang tua terhadap motivasi akademik siswa. Hasil penelitian menunjukkan terdapat hubungan yang 
signifikan antara peran orang tua dengan motivasi akademik, dengan nilai sig 0,000<0,05 dan nilai $r$ tabel 0.709 .

Tabel 1. Hasil Analisis Korelasi Peran Orang Tua dan Motivasi Akademik

\begin{tabular}{llcc}
\hline \multicolumn{3}{c}{ Correlations } \\
\hline & \multicolumn{1}{c}{ Peran Orang Tua } & Motivasi Akademik \\
\hline Peran Orang Tua & Pearson Correlation & 1 &, $709^{* *}$ \\
& Sig. (2-tailed) & 144 &, 000 \\
& $\mathrm{~N}$ &, $709^{* *}$ & 144 \\
Motivasi Akademik & Pearson Correlation & 000 & 1 \\
& Sig. (2-tailed) & 144 & 144 \\
& $\mathrm{~N}$ & & \\
\hline **. Correlation is significant at the 0.01 level (2-tailed).
\end{tabular}

Hasil analisis yang ditunjukkan pada tabel 1 di atas menunjukkan ditemukan hubungan positif antara peran orang tua dengan motivasi akademik. Artinya semakin tinggi peran orang tua maka motivasi akademik siswa dapat meningkat. Hal ini dapat dilihat pada nilai pearson correlation yang menunjukkan hasil positif yaitu 0,709 .

\subsection{Pembahasan}

\subsubsection{Motivasi}

Motivasi dimaknai sebagai dorongan kekuatan yang menyebabkan individu bertindak melakukan kegiatan tertentu. Dalam kamus besar bahasa Indonesia (Depdikbud 1996) motivasi dimaknai sebagai dorongan yang timbul dari dalam diri individu, baik disadari maupun tidak disadari untuk bertindak mencapai tujuan. Schunk (2012) menyatakan bahwa motivasi berhubungan dengan tujuan, aktivitas dan ketekunan. anak yang memiliki kemampuan yang kuat akan berupaya secara terus menerus dan ketika menghadapi hambatan dan tantangan mereka akan terus dengan semangat akan bertahan dan bahkan berjuang untuk dapat memecahkan masalah. Motivasi juga dapat diartikan sebagai daya penggerak yang tidak nampak namun ada dan dapat menjadi pendorong yang sangat kuat bagi murid untuk mencapai tujuan. (Lidia, 2020)

Motivasi sangat penting dalam kehidupan anak karena motivasi sebagai pendorong tumbuh kembang anak dalam kegiatan sehari hari, ketika anak tidak memiliki motivasi dalam belajar maka tugas dan kewajiban mereka dalam belajar tidak akan tercapai seperti yang diharapkan. Saat anak mendapat tugas sesuai perkembangan mereka sebagai remaja maka mereka akan bersemangat untuk dapat menyelesaikan tugas dengan baik dan tepat waktu. Motivasi ibarat bahan bakar yang dapat habis setiap waktu, maka motivasi harus selalu dipantau volumenya dan diisi agar menghasilkan tenaga kembali untuk bergerak.

Motivasi merupakan bagian penting dalam pembelajaran, karena motivasi dapat mendorong seseorang untuk mau bergerak melakukan sesuatu sesuai dengan tujuan, dalam hal ini adalah belajar. Winkel (dalam Puspitasari 2012) menyatakan motivasi belajar sebagai usaha individu untuk melakukan, mengarahkan, dan menjamin kelangsungan kegiatan belajar dalam rangka mencapai tujuan yang diinginkan. Motivasi belajar merupakan salah satu faktor 
non-kognitif yang berperan penting untuk menumbuhkan semangat belajar dalam diri individu.

Ari (2010:12) menyatakan bahwa keberhasilan individu dalam belajar jika dalam dirinya terdapat keinginan untuk belajar. Sedangkan, motivasi belajar membantu anak mencapai tujuan yang diinginkan. Motivasi yang berkembang dalam diri seseorang secara umum muncul dan datang dari dalam diri individu dapat disebut motivasi intrinsik, sedangkan dorongan yang bersumber dari luar diri individu disebut motivasi ekstrinsik. Amna (2017) menambahkan motivasi dapat diklasifikasikan menjadi dua yaitu motivasi intrinsik dan ekstrinsik. Motivasi intrinsik merupakan dorongan yang berasal dari dalam diri untuk belajar, sedangkan motivasi ekstrinsik merupakan dorongan dari luar diri individu untuk belajar.

Motivasi belajar intrinsik dapat muncul tanpa adanya paksaan dari orang lain dan benarbenar dari dalam diri individu. Contohnya saat murid belajar dan mereka ingin mengetahui jawaban dari permasalahan yang mereka alami maka dia akan dengan sadar dan yakin berupaya untuk menemukan jawaban dari permasalahan tersebut dengan giat belajar. Sedangkan motivasi ekstrinsik merupakan dorongan yang muncul sebagai akibat adanya pengaruh dari luar individu dan dapat bersifat paksaan maupun ajakan, atau tugas sehingga kondisi tersebut mendorong anak untuk mau belajar.

Peningkatan Motivasi intrinsik dari anak ini sejalan dengan filosofi Pendidikan menurut Ki Hajar Dewantara. Motivasi intrinsik ini yang sangat dibutuhkan anak dalam pembelajaran daring, mengingat pengawasan mereka dalam belajar mengalami perubahan dikarenakan pandemi, jika disekolah dapat langsung diawasi oleh guru. Sedang di rumah, orang tualah yang memiliki kesempatan dalam melakukan pengawasan terhadap anak. Namun jika orangtua dari sang anak tidak dapat mendampingi tumbuh kembangnya anak saat jam pelajaran daring berlangsung, maka motivasi intrinsik inilah yang menjadi penyelamat proses tumbuh kembangnya anak dalam pembelajaran di era pandemi.

Bapak pendidikan Indonesia Ki Hajar Dewantara mengajarkan kita untuk dapat mengembangkan motivasi intrinsik anak untuk membentuk karakter bertanggung jawab, penuh inisiatif, menghargai diri sendiri dan orang lain. Begitupun filsafat beliau yang menjelaskan pentingnya motivasi intrinsik sebagai upaya menumbuhkan murid merdeka di sekolah. Perbuatan yang didasarkan motivasi intrinsik akan cenderung menjadi perilaku yang menetap yang dapat disebut karakter, maka sangat penting untuk meningkatkan motivasi intrinsik dalam diri siswa.

\subsubsection{Peran Orang Tua}

Orangtua merupakan sosok pendidik pertama bagi anak, artinya dapat dikatakan bahwa keluarga merupakan pendidikan pertama bagi anak (Dzaliyah, 2012). Ningrum (2012) menyatakan bahwa madrasah pertama bagi anak adalah orang tua dan tanpa orang tua, pendidikan yang layak tidak akan bisa didapatkan. Oleh karena itu anak perlu mendapatkan bimbingan dan pengawasan yang teratur agar anak tidak kehilangan kemampuan berkembang secara normal. Orangtua merupakan madrasah pertama yang memberikan pengajaran di rumah. Peran orangtua sangat penting dalam menghantarkan anak belajar. Orangtua menjadi dasar pendidikan bagi anak, bahkan berperan penting untuk membimbing dan memberikan kekuatan pada anak (Ari 2010). 
Orang tua berperan penting dalam kehidupan anak menuju masa dewasa. Di Dalam keluarga orangtua memegang peranan penting dikarenakan mereka adalah penanggung jawab utama terselenggaranya pendidikan di dalamnya (Mardiani 2021). Nasution (1985) menyatakan bahwa orang tua berperan untuk memberikan bimbingan belajar pada anak di rumah dalam rangka mengatasi masalah yang dialami selama proses belajar, melakukan pemantauan terhadap jadwal anak, baik di sekolah maupun di rumah, memberikan reward maupun punishment pada anak, dan memperhatikan kesehatan anak. Orang tua dapat berperan serta dalam memberikan perhatian dan pengawasan pendidikan dengan cara melatih, sekaligus mendorong anak agar dapat hidup mandiri sesuai dengan tahapan perkembangan, antara lain berani untuk mengatasi masalah dan memupuk kepercayaan diri.

Sejak 16 Maret 2020 pemerintah mencanangkan semua aktivitas dibatasi, termasuk pembelajaran, jika dulu guru melakukan proses kegiatan belajar mengajar dengan bertemu langsung, namun dikarenakan pandemi akhirnya merubah pola pengajaran menjadi daring/online. banyak guru yang belum terbiasa dengan pola tatap muka secara virtual, sehingga mengalami kebingungan dalam melakukan proses kegiatan belajar mengajar secara daring. Adanya Sosial Distancing tersebut juga memberikan batasan ruang dan dan waktu dalam sistem pembelajaran pada setiap jenjang pendidikan. mulai dari pra sekolah, sekolah dasar dan menengah.

Tujuan penelitian untuk mengetahui hubungan antara peran orang tua terhadap motivasi akademik anak. Hasil penelitian mengkonfirmasi bahwa ditemukan hubungan positif antara peran orang tua dan motivasi akademik. Kenapa sangat penting penelitian ini dilakukan karena motivasi adalah energi dalam diri manusia yang dapat memberikan dorongan dan semangat dalam mencapai tujuan yang diharapkan. Rumhadi (2017) menyatakan bahwa motivasi berperan penting dalam membantu upaya individu untuk mencapai tujuan yang diharapkan dalam bidang pendidikan maupun bidang lainnya. Saputra (2018) menambahkan dalam kegiatan belajar membutuhkan motivasi untuk mendorong individu dapat mencapai hasil belajar yang optimal. Motivasi hadir sebagai salah satu faktor yang berperan penting untuk membantu individu mencapai prestasi yang diharapkan. Bahkan, motivasi membantu individu untuk kuat dan berusaha keras mencapai tujuan.

\section{Simpulan}

Hasil penelitian menunjukkan terdapat hubungan yang positif antara peran orangtua dan motivasi belajar, itu artinya jika variabel peran orangtua ditingkatkan maka motivasi akademik siswa juga meningkat. Motivasi dengan faktor intrinsik akan membantu anak menyelesaikan tahapan dalam belajar dan mengembangkan diri menjadi mandiri. Peran orang tua sangat berarti dalam memberi pendampingan dan mengarahkan anak menyelesaikan tugas perkembangan dan hambatan belajarnya, dengan pendampingan orang tua dapat meningkatkan motivasi belajar anak dengan maksimal dan menghasilkan berprestasi.

\section{Daftar Rujukan}

Astuti, A. E. (2010). Hubungan antara peran orang tua dan motivasi belajar dengan prestasi belajar mata pelajaran sosiologi pada siswa kelas XI Sma Negeri 1 Karangdowo, Klaten Tahun Ajaran 2009/2010.

Astuti, A. E. (2010). Hubungan antara peran orang tua dan motivasi belajar dengan prestasi belajar mata pelajaran sosiologi pada siswa kelas XI Sma Negeri 1 Karangdowo, Klaten Tahun Ajaran 2009/2010.

Cahyani, A., Listiana, I. D., \& Larasati, S. P. D. (2020). Motivasi Belajar Siswa SMA pada Pembelajaran Daring di Masa Pandemi Covid-19. IQ (Ilmu Al-qur'an): Jurnal Pendidikan Islam, 3(01), 123-140. 
Jurnal Pembelajaran, Bimbingan, dan Pengelolaan Pendidikan, 1(10), 2021, 855-860

Coskun, K., \& Topkaya, Y. (2020). Is procedural knowledge of recycling correlated with socioeconomic status and residential area?. Applied Environmental Education \& Communication, 19(4), 329-348.

Depdikbud. (1996). Kamus Besar Bahasa Indonesia. Jakarta: Balai pustaka.

Emda, A. (2018). Kedudukan motivasi belajar siswa dalam pembelajaran. Lantanida Journal, 5(2), 172-182.

Krepelkova, Š. D., Krajhanzl, J., \& Kroufek, R. (2020). The Influence of Interaction with Nature in Childhood on Future Pro-environmental Behavior. Journal of Baltic Science Education, 19(4), 536-550.

Lidia Susanti, S. P. (2020). Strategi pembelajaran berbasis motivasi. Elex Media Komputindo.

Mills, T., \& Mills, F. (2020). Correlation, causation, and David Hume. Australian Mathematics Education Journal, 2(4), 44-48.

Robandi, D., \& Mudjiran, M. (2020). Dampak pembelajaran dari masa pandemi covid-19 terhadap motivasi belajar siswa SMP di Kota Bukittinggi. Jurnal Pendidikan Tambusai, 4(3), 3498-3502.

Sari, I. K. (2021). Analisis Faktor Penyebab Rendahnya Motivasi Belajar Siswa Sekolah Dasar Selama Pembelajaran Daring. Jurnal Basicedu, 5(4), 2156-63. 